\title{
HLBT-100: a highly potent anti-cancer flavanone from Tillandsia recurvata (L.) L.
}

\author{
Henry I. C. Lowe ${ }^{1,2,3}$, Ngeh J. Toyang ${ }^{2,3}$, Charah T. Watson', Kenneth N. Ayeah ${ }^{2,3}$ and Joseph Bryant ${ }^{3 *}$
}

\begin{abstract}
Background: The incidence and mortalities from cancers remain on the rise worldwide. Despite significant efforts to discover and develop novel anticancer agents, many cancers remain in the unmet need category. As such, efforts to discover and develop new and more effective and less toxic agents against cancer remain a top global priority. Our drug discovery approach is natural products based with a focus on plants. Tillandsia recurvata (L.) L. is one of the plants selected by our research team for further studies based on previous bioactivity findings on the anticancer activity of this plant.

Methods: The plant biomass was extracted using supercritical fluid extraction technology with $\mathrm{CO}_{2}$ as the mobile phase. Bioactivity guided isolation was achieved by use of chromatographic technics combined with anti-proliferative assays to determine the active fraction and subsequently the pure compound. Following in house screening, the identified molecule was submitted to the US National Cancer Institute for screening on the NCI60 cell line panel using standard protocols. Effect of HLBT-100 on apoptosis, caspase 3/7, cell cycle and DNA fragmentation were assessed using standard protocols. Antiangiogenic activity was carried out using the ex vivo rat aortic ring assay.

Results: A flavonoid of the flavanone class was isolated from T. recurvata (L.) L. with potent anticancer activity. The molecule was code named as HLBT-100 (also referred to as HLBT-001). The compound inhibited brain cancer (U87 MG), breast cancer (MDA-MB231), leukemia (MV4-11), melanoma (A375), and neuroblastoma (IMR-32) with IC 50 concentrations of $0.054,0.030,0.024,0.003$ and $0.05 \mu \mathrm{M}$, respectively. The molecule also exhibited broad anticancer activity in the NCl60 panel inhibiting especially hematological, colon, CNS, melanoma, ovarian, breast and prostate cancers. Twenty-three of the NCI60 cell lines were inhibited with $\mathrm{Gl}_{50}$ values $<0.100 \mu \mathrm{M}$. In terms of potential mechanisms of action, the molecule demonstrated effect on the cell cycle as evidenced by the accumulation of cells with $<$ G1 DNA content, activation of caspase 3/7, DNA fragmentation and culminating in apoptotic cell death. HLBT100 also demonstrated antiangiogenic potential by inhibiting capillary sprout and tube formation in a dose dependent manner in the ex vivo rat aortic ring.
\end{abstract}

Conclusion: This paper describes for the first time the anticancer activity of HLBT-100 isolated from T. recurvate (L.) L. The broad and selective anticancer activity of HLBT-100 as evidenced by its potent activity against IMR-32, CNS cancer cell line while not active against neuro-2a, a normal CNS cell line. The activity demonstrated by HLBT-100 in these studies makes the molecule a potential candidate for further development targeting especially those cancers that remain in the unmet need category such as glioblastoma multiforme and acute myeloid leukemia in addition to other cancers.

Keywords: Tillandsia recurvata, Flavanone, Anticancer, Angiogenesis, Ball Moss

\footnotetext{
${ }^{*}$ Correspondence: jbryant@ihv.umaryland.edu

${ }^{3}$ Institute of Human Virology, University of Maryland School of Medicine,

725 W Lombard St, Baltimore, MD, USA

Full list of author information is available at the end of the article
} 


\section{Background}

According to recent statistics from the National Cancer Institute (NCI) and the World Health Organization (WHO), there will be about 14.1 million new cancer cases diagnosed globally in 2016 out of which about 1.7 million cases will be in the United States of America (USA) [1-3]. Expenditure associated with cancer care in USA was about US\$125 billion in 2010 and it is estimated to reach US\$156 billion by 2020 [3]. Cancer as such remains a major worldwide health problem and one of the top causes of death [4]. The search for new, effective and less toxic anticancer drugs as such remains a major global priority. The US government for example has declared cancer a major health problem and is now increasing funding for research and development of new cancer treatments through the newly established Cancer Moonshot project which aims to enhance early detection and prevention of cancer including expanding research in the area of immuno-oncology [5].

For several decades, the world depended on nature as a source of new biologically active molecules as evidenced by the discovery of drugs such as penicillin, quinine, Taxol, vinca alkaloids, metformin and several others [6]. Natural products especially from plants have made significant contributions to the discovery and development of new drugs particularly against cancer [7]. Given the previous success recorded in drug discovery from nature, we decided to base our drug discovery effort on plants given the rich diversity of chemical structures that exist in plants as secondary metabolites $[8,9]$.

Tillandsia recurvata L. (Bromeliaceae) also known as the Jamaican Ball Moss or the Old Man's beard is an aerial plant often found growing on tree branches or on telephone and electricity poles or cables [10]. Plants from the Bromeliaceae family have a unique capability to survive harsh drought conditions but never seem to die as the leaves come back to life within hours of rehydration and as such, these plants are also known as the "resurrection plants" [11]. Previous studies by our group found T. recurvata to be having various chemical constituents including terpenoids and flavonoids [12,13]. Screening of the extracts of $T$. recurvata also revealed that the plant possesses several pharmacological properties including, anticancer activity [14, 15]. Some of the specific compounds previously isolated from the plant includes cycloartanes, cinnamoyl diccinamates and phenolic compounds $[12,13,15]$. Anti-angiogenic activity and kinase inhibition are some of the specific mechanisms of action demonstrated by the extracts or compounds isolated from $T$. recurvata [16-18]. Based on the activity demonstrated by the crude extract of $T$. recurvata, this study was carried out in an attempt to further isolate and characterize the anticancer molecules present in the plant.
In this study, HLBT-100 isolated from $T$. recurvata has been identified to be a flavonoid with hitherto unreported anticancer activity. Flavonoids are widely distributed in the plant kingdom with over 4000 structures described making flavonoids the largest class of plant secondary metabolites $[19,20]$. Flavonoids have a characteristic color ranging from pale to deep orange and their basic backbone structure includes two fused rings linked to an aromatic ring [21-23]. Flavonoids are sub-divided into six classes including flavanols, flavonols, flavones, flavanones, isoflavones and anthocyanidins $[24,25]$. In plants, the primary significance of flavonoids is to provided pigmentation required for UV-radiation protection as well as defense from pests and disease [26-28]. In the human sphere, flavonoids provide a wide range of benefits including use in diet and health [20] and are credited for possessing antimicrobial, antiviral, cancer chemoprevention, neurodegenerative properties and cardiovascular health benefits among several other health properties [29-33]. Flavonoids as such hold promise as potential cures for mankind and require increased scientific attention.

\section{Results}

\section{Chemical characterization of HLBT-100}

Using spectroscopic analysis including mass spectrometry (MS) and nuclear magnetic resonance (NMR) studies, the chemical structure of the yellowish powder obtained was elucidated. The molecule was putatively code named HLBT-001 (5,3'-dihydroxy$6,7,8,4^{\prime}$-tetramethoxyflavanone) and was renamed HLBT-100 once the structure elucidation was completed (Fig. 1). A thorough search of the literature revealed that the compound had previously been isolated from T. recurvata [12] but no bioactivity studies were carried out or reported for the molecule. HLBT-100 belongs to the flavanone class of flavonoids which is characterized by a single bond between $\mathrm{C} 2$ and $\mathrm{C} 3$ of the heterocycle ring " $\mathrm{C}$ " compared to the closely related flavonol and flavone classes of flavonoids (Fig. 1). HLBT-100 is highly

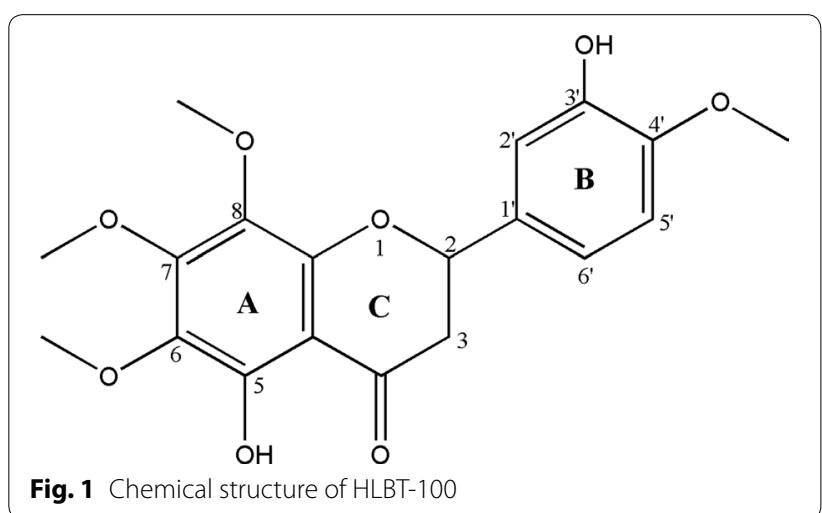


polymethoxylated and most of the polymethoxylated flavanones have previously been isolated mostly from citrus plants of the Rutaceae family $[34,35]$.

\section{Antiproliferative activity}

To determine the antiproliferative activity of HLBT-100 against cancer cell lines, the brain cancer cell line (U87 MG), breast cancer cell line (MDA-MB-231), human melanoma (A375), leukemia (MV4-11) and prostate cancer (PC-3) cell lines were subjected to the WST-1 antiproliferative assay. HLBT-100 in a dose dependent manner inhibited the proliferation of cancer cells at sub-micromolar concentrations with $\mathrm{IC}_{50}$ values ranging from 0.004 to $0.054 \mu \mathrm{M}$ (Fig. 2). Upon being subjected to anticancer activity screen on the NCI60 panel, HLBT100 demonstrated potent activity against 23 of the cell 60 lines on the NCI cancer cell line panel with $\mathrm{GI}_{50}$ values $<0.100 \mu \mathrm{M}$ (Fig. 3).

\section{Cell viability assay}

To assess the cell viability and selectivity effect of HLBT100, the Cell Titer-Glo luminescent cell viability assay kit was used. The neuroblastoma cancer cell line (IMR-32) and normal neuroblastoma cells (nuero-2a) were subjected to this assay. The compound showed great selectivity by killing the cancer cells (IMR-32) while having no effect against the normal human cell line (nuero-2a) (Fig. 4).

\section{Cell cycle arrest and apoptosis}

The effect of HLBT-100 on cell cycle arrest and apoptosis was determined using, the propidium iodide flow cytometry kit and the Annexin V-FITC apoptosis detection Kit. Cell cycle significantly affected as accumulation of cells with $<$ G1 DNA content were at $24 \mathrm{~h}, 48 \mathrm{~h}$ and $72 \mathrm{~h}$ of

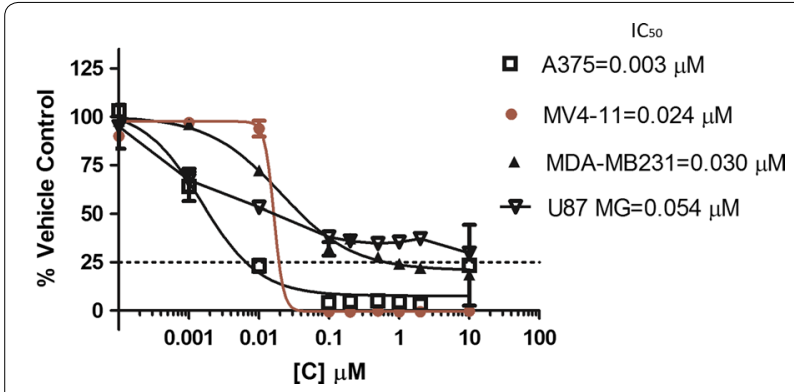

Fig. 2 WST-1 assay results for HLBT-100 in $72 \mathrm{~h}$ against MV4-11, MDA-MB231. PC-3, A375 and U87 MG. Following treatment of cells, dose response curves were plotted and IC $\mathrm{C}_{50}$ values calculated using graphpad prism software. The mean IC50s and standard deviations generated are as follows: MV4-11 $=0.024 \pm 0.001 \mu \mathrm{M}$; MDA-MB231 $=0.030 \pm 0.008 \mu \mathrm{M} ; \mathrm{PC}-3=0.031 \pm 0.011 \mu \mathrm{M}$; $\mathrm{A} 375=0.004 \pm 0.003 \mu \mathrm{M} ; \mathrm{U} 87 \mathrm{MG}=0.054 \pm 0.006 \mu \mathrm{M}$ incubation at the $5 \times \mathrm{IC}_{50}$ in the MV4-11 cell line (Fig. 5). In regards to apoptosis effect, HLBT-100 caused significant apoptotic effect $(>70 \%)$ at $5 \times$ of it's $\mathrm{IC}_{50}$ against MV4-11 cells after $24 \mathrm{~h}$ (Fig. 6).

\section{In-cell DNA fragmentation induced by HLBT-100}

DAPI nuclear staining showed DNA was fragmented in cells treated with the compound compared to vehicle treated cells (Fig. 7). Maximum cleavage was found with the $72 \mathrm{~h}$ treatment with HLBT-100 against all the cell lines tested. Non apoptotic cells showed non-cleaved intact bigger round chromosomal DNA whereas apoptotic cells showed cleaved nuclei.

\section{Caspase $3 / 7$ activity}

To determine if HLBT-100 induces apoptosis via a caspase dependent pathway, the activation effect of HLBT-100 on caspase 3/7 was evaluated. Apoptosis is orchestrated by a family of cysteine proteases known as the caspases. Of the fourteen mammalian caspases identified, caspase $3 / 7$ are thought to coordinate the execution phase of apoptosis by cleaving multiple structural and repair proteins [36]. HLBT-100 upregulated the expression of caspase 3/7 in this study in a dose dependent manner (Fig. 8).

\section{Angiogenesis}

The antiangiogenic properties of HLBT-100 were determined using the ex vivo rat aortic ring and in vitro tube formation assays. HLBT-100 demonstrated antiangiogenic activity by inhibiting capillary sprout formation in rat aorta rings (Fig. 9).

\section{Discussion}

The Jamaican Ball Moss continues to demonstrate that it harbors significant bioactive molecules especially against cancer. In this study, we successfully isolated and characterized HLBT-100 from $T$. recurvata as a new anticancer flavonoid (Fig. 1). The potency of HLBT-100 in vitro at sub-micromolar concentrations against both solid and hematological cancers makes HLBT-100 a potential anticancer agent (Figs. 2, 3). HLBT-100 belongs to the flavonoid class of compounds. Flavonoids occur widely in fruits and commonly eaten foods and as such are mostly considered to be safe and as such are used widely for food and disease prevention [30,37]. Routine consumption of fruits and flavonoid rich foods has long been linked to a lower incidence of several diseases including cancer, neurodegenerative diseases, cardiovascular disease, metabolic disease and immune function modulation [31, 38-44].

HLBT-100 however appears to be a unique molecule as it has not been isolated from any other plant than from T. recurvata which is not known to be used as a food 


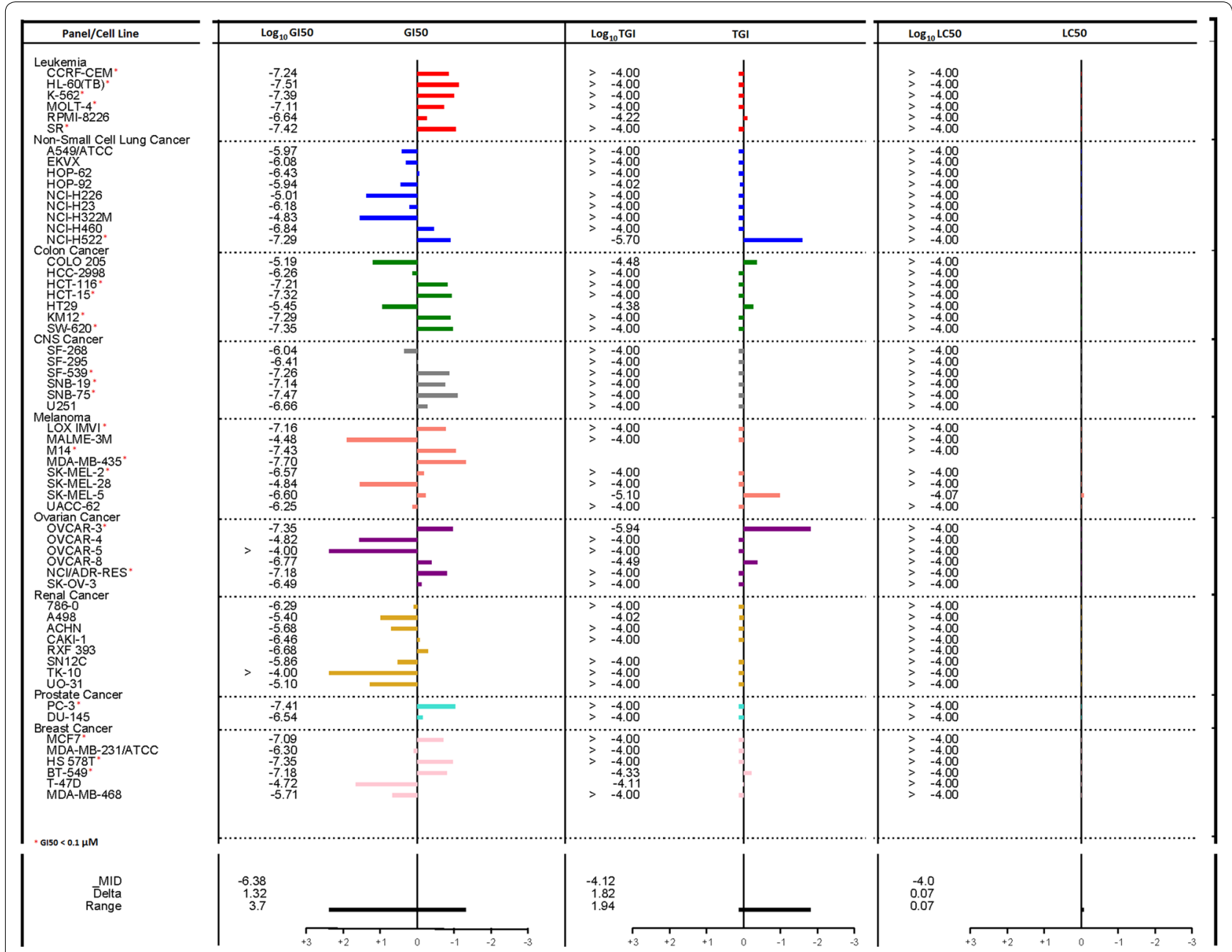

Fig. 3 Anticancer activity of HLBT-100 on the NCl60 cancer cell line panel. The compound was first screened at a single concentration of $100 \mu \mathrm{M}$ and having satisfied the NCI predetermined threshold (data not shown), the molecule was subjected 5-dose response screen

plant anywhere [12]. The molecule was identified as a flavanone which has an aglycone that is structurally different from the commonly used flavonoids such as the flavones including compounds such as apeginin, luteolin, kaempferol and quercetin. The major difference between a flavanone and a flavone is the number of bonds between carbons 2 and 3 of the aglycone (Fig. 1). While flavanones have a single bond, flavones have a double bond between carbons 2 and 3 . This structural difference seem to confer flavanones with a superior anticancer activity compared to flavanones. For example, Cabrera et al. [45] screened over 50 flavonoids against 3 human cancer cell lines and the most active compounds against the cell lines screened were flavonoid precursors (chalcones) followed by flavanones ahead of the flavones. Even though widely distributed, the flavanones are more commonly found in plants of the citrus family $[46,47]$.
In the current studies, HLBT-100 demonstrated a dose dependent inhibition of cancer cell lines (Fig. 2). The most sensitive cell line in these studies was the human melanoma cell line (A375) even though activity against the other cancers was also considered to be potent given the sub-micromolar $\mathrm{IC}_{50}$ values exhibited. The activity demonstrated against 23 of the 60 cell lines on the NCI60 cancer cell line panel validated the in house anticancer activity demonstrated during the preliminary screen of this molecule (Fig. 3). The NCI60 cancer cell line panel which was established in the 1960s to enhance the discovery and development of novel anticancer agents has been used for several decades as reference tool for cancer drug discovery and is credited for the discovery and development of a number of important anticancer agents in clinical use today [48-50]. The molecule demonstrated selectivity and potently inhibited all the cancer cell lines 

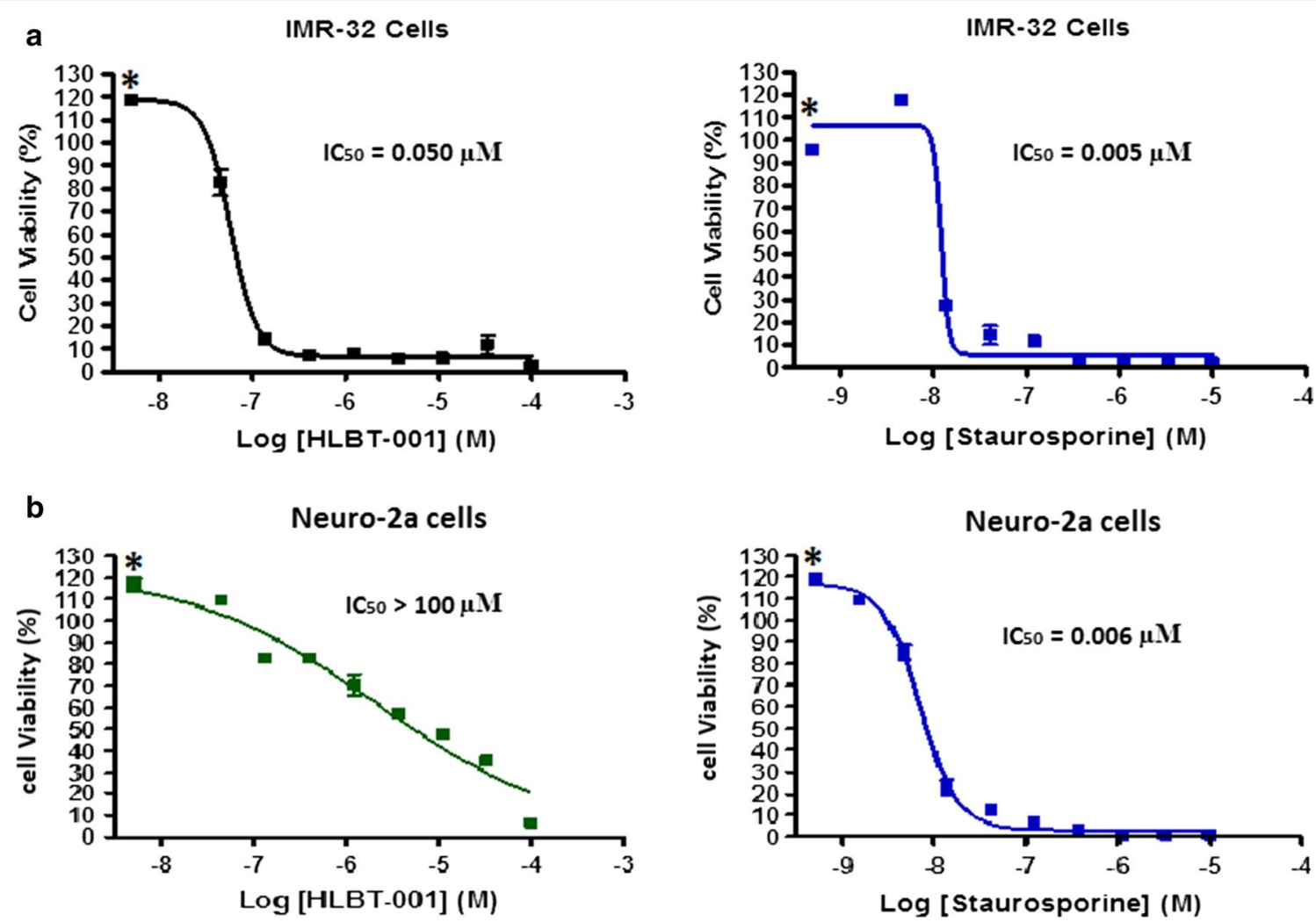

Fig. 4 Effect of HLBT-100 on cell viability. Cells were seeded at 2000-5000 cells/well in 96-well plates. After an overnight incubation, cells were treated with HLBT-100 a IMR-32 nueroblastoma cancer cell line and $\mathbf{b}$ neuroblastoma normal cells, and incubated for $72 \mathrm{~h}$ at $37^{\circ} \mathrm{C}$. The cell viability was determined using the Cell Titer-Glo luminescent cell viability assay kit after staining for 10 min, according to the manufacturer's instructions. The $I_{50}$ values were generated using graphpad prism. Staurosporine (graphs on the right) was used as a positive control against both cell lines. Asterisk Lower concentrations of HLBT-100 versus control are slightly above 100\% of control because of "edge effect" where slight evaporation of media in control wells on the edge of plate might result in lower OD values for those wells

in the leukemia panel while it was inactive against 7 out of the 8 cell lines in the renal cancer panel. Most importantly, the compound showed the ability to selectively inhibit cancer cells while sparing normal cells as demonstrated in its cytotoxicity towards the neuroblastoma cancer cell line IMR-32 while having no activity against the normal neuro-2a cells (Fig. 4). The neuro-2a cell line is currently viewed as a useful tool to screen novel compounds for potential neurotoxic properties [51]. The lack of toxicity against neurons by HLBT-100 is an early indication that the molecule may possess a very good safety profile.

Apoptosis which is a physiological rather accidental cell death is crucial in the control of the proliferation of cancer cells [52]. While there are a number of mechanisms and molecular events by which apoptosis is elicited, HLBT-100 in this study showed that it activates caspase 3/7, DNA fragmentation and significant effect on cell cycle as (Figs. 5, 7, 8). Caspases are genes that regulate homeostasis through the regulation of cell death and caspase-3, -6 and -7 are considered executioner caspases in the apoptosis process while caspases-2, -8 -9 and -10 are the effector kinases $[53,54]$. DNA cleavage is another hallmark of apoptosis and cells treated with HLBT-100 showed significant DNA cleavage following DAPI staining $[55,56]$. One of the widely studied flavanones is naringenin which demonstrated GO/G1 G2/M phase arrest in cell cycle studies even though at significantly higher concentrations $(>20 \mu \mathrm{M})$ compared to HLBT-100 $(<0.15 \mu \mathrm{M})[46,57]$. Most of the commonly used flavonoids have been reported to play a role in cancer chemoprevention through the apoptosis signaling pathway and as such it is not surprising that HLBT-100 exhibits potent apoptosis signaling and at concentrations much less than those exhibited by other commonly used flavonoids [58-60].

Angiogenesis is simply defined as the process by which new vessels are developed and this has significant implication in disease especially tumors which need new vessels for the supply of nutrients $[61,62]$. Capillary sprouts 

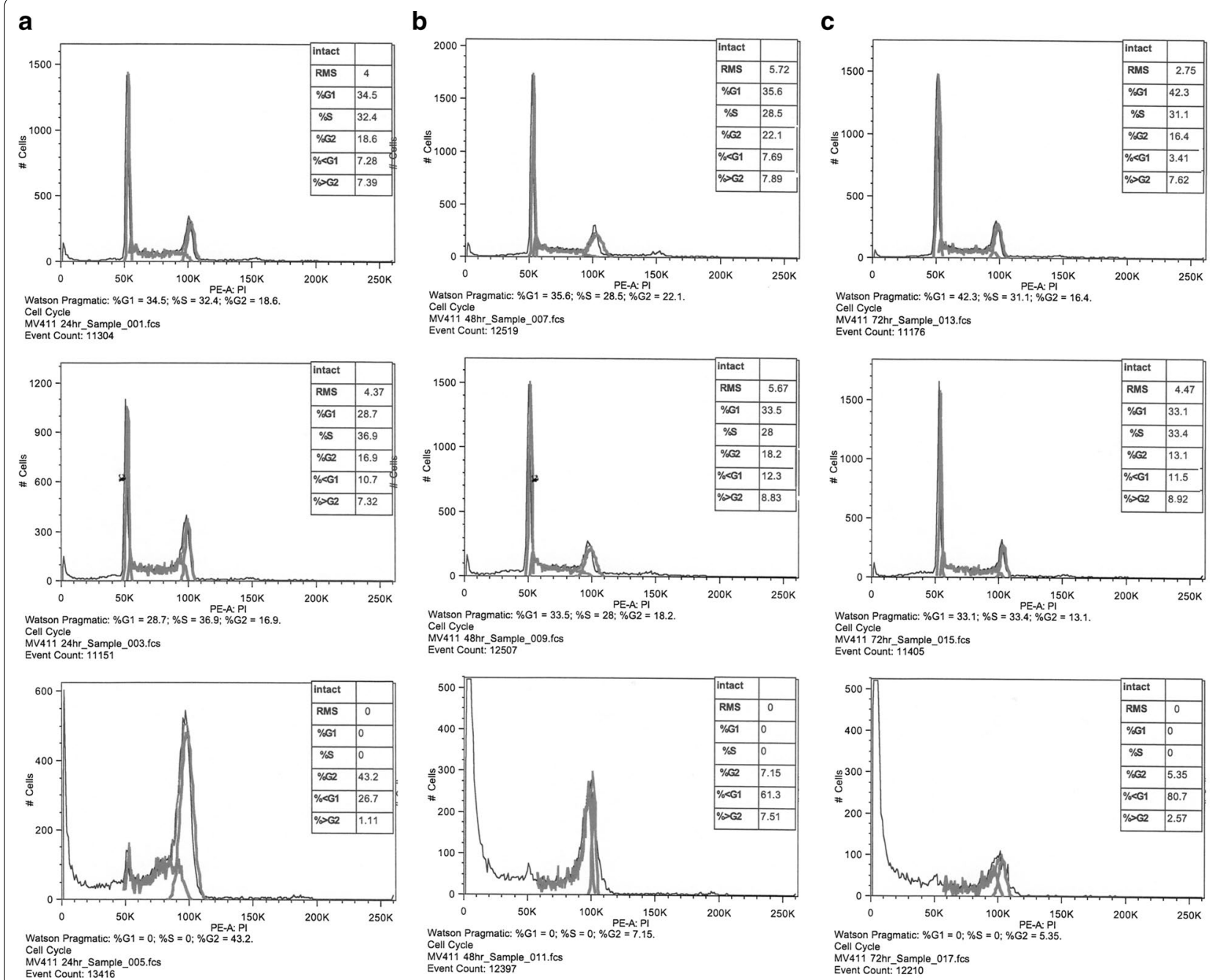

Fig. 5 Cell cycle effect of HLBT-100. For cell cycle effect determination, MV4-11 leukemic cell line was used. Cells were treated with either DMSO: top row (vehicle) or HLBT-100: middle row $(0.024 \mu \mathrm{M})$ and bottom row $(0.120 \mu \mathrm{M})$. Cell were incubated at $37^{\circ} \mathrm{C}$ and at $24 \mathrm{~h}(\mathbf{a}), 48 \mathrm{~h}(\mathbf{b})$ and $72 \mathrm{~h}(\mathbf{c})$, cells were harvested, washed and stained according to the manufacturer's recommendations with the Abcam propidium iodide flow cytometry kit. Acquired samples were analyzed using FlowJo (Tree Star, Ashland, OR, USA)

as demonstrated by the ex vivo rat aortic ring assay are important in cancer progression as they are known to be representative of all phases of angiogenesis [63]. Several flavonoids including flavopiridol, quercetin, apigenin and naringenin are credited for exhibiting antiangiogenic properties and this property is thought play a role in their antitumor and cancer chemoprevention potential [64-68]. Angiogenesis is also required for cell invasion and migration and as such a necessary conduit for cancer metastasis [66]. Angiogenesis inhibitors are among several anticancer agents that are currently in clinical use and because most of them are kinase inhibitors plagued with resistance issues, there is a need for the discovery and development of new antiangiogenic agents $[69,70]$. While the mechanism of action of most antiangiogenic inhibitors involve the inhibition of protein kinases (e.g. VEGFR), the mechanism of inhibition of angiogenesis by HLBT-100 among other mechanism of action studies remain to be determined.

The development of flavonoids into standard drugs remains a challenge despite the plethora of preclinical data that has been reported on their pharmacological properties [20]. Their therapeutic use have been hindered by poor drug-likeness properties to low bioavailability. This attributes accounts for why there are only a handful of flavonoid based molecules currently in clinical trials to-date and includes flavopiridol (alvocidib) (Tolero Pharmaceuticals, Inc.) and Icaritin (Shenogen Pharma, China) [71-73]. To overcome the preclinical development of 


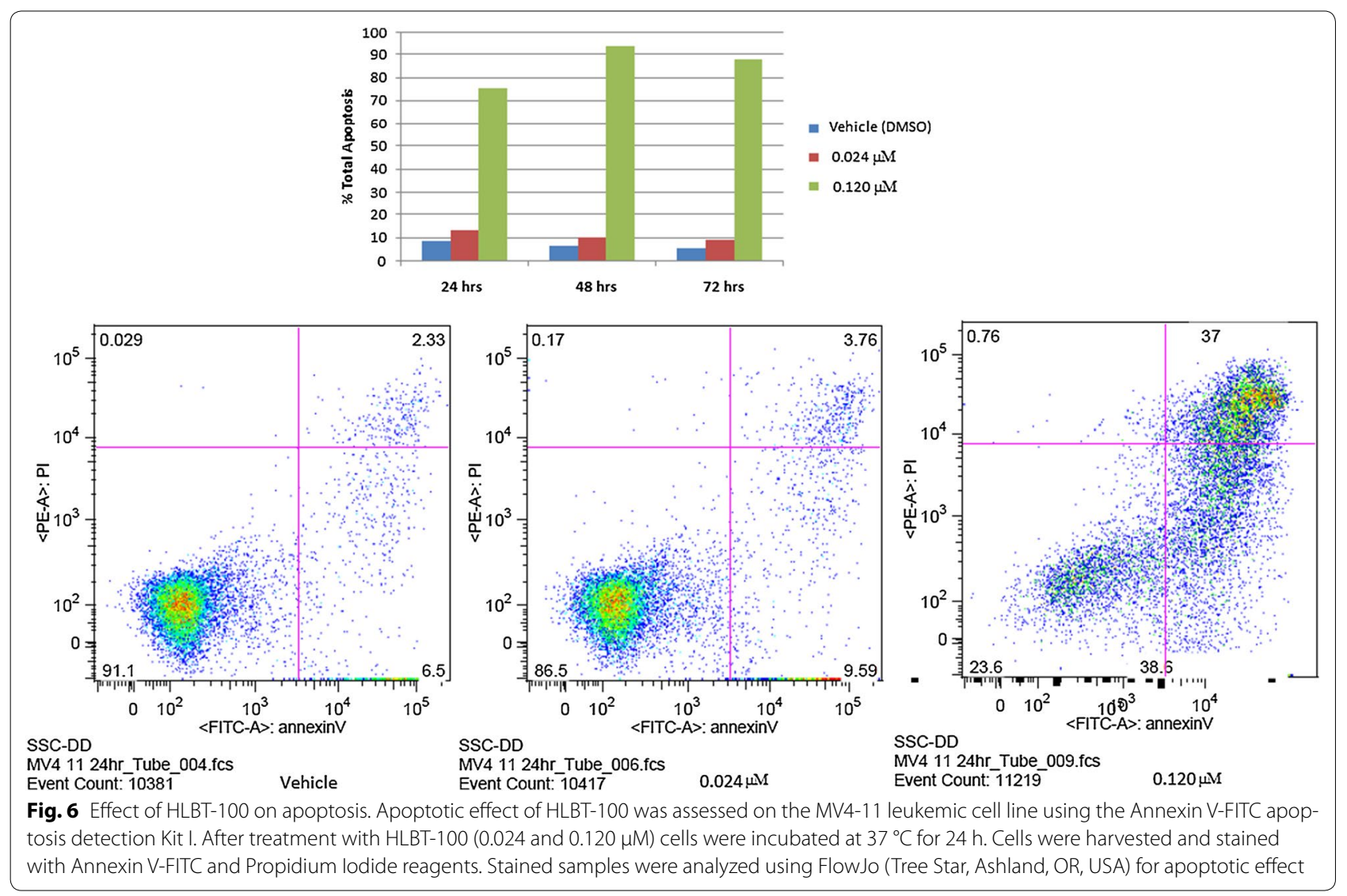

HLBT-100, a number of approaches including the use of polymer and nanotechnology drug delivery approaches might be required to overcome especially poor bioavailability challenges.

\section{Conclusion}

This paper describes for the first time the anticancer activity of HLBT-100 isolated from $T$. recurvata. The identification of possible anticancer properties including effect on apoptosis and angiogenesis requires further studies to identify the specific molecular and cellular pathways responsible for the observed activity. Further studies are in progress to identify other possible mechanisms of action as well as in vivo efficacy and safety. The broad and selective anticancer activity of HLBT-100 was evidenced by its potent activity against IMR-32, CNS cancer cell line while inactive against neuro-2a, a normal CNS cell line. The activity demonstrated by HLBT-100 in these studies makes the molecule a potential candidate for further development targeting especially those cancers that remain in the unmet need category such as glioblastoma multiforme and acute myeloid leukemia in addition to other cancers neuroblastoma, lymphoma and leukemia.

\section{Methods}

Compound extraction and isolation

The fresh plant material was collected from power lines in Jamaica after which it was air dried under shed away from direct sunlight, then milled and extracted using supercritical fluid extraction (SFE) technology. The extraction parameters on the SFE were set as follows: pressure (200 bars); temperature (heat exchanger $-45{ }^{\circ} \mathrm{C}$, extracting vessel $-40{ }^{\circ} \mathrm{C}$ and collecting vessel $\left.-40{ }^{\circ} \mathrm{C}\right)$; solvent $\left(\mathrm{CO}_{2}\right.$ and $10 \%$ ethanol); flow rate $(9 \mathrm{ml} / \mathrm{min})$ and run time $(60 \mathrm{~min})$. Isolation of the bioactive fractions was done in two phases. First, solvent/ solvent partition was carried out to separate the lipid soluble from the mid-polar fraction using a combination of methanol, ethyl acetate and $\mathrm{DiH}_{2} \mathrm{O}$. The two fractions were subjected to bioactivity screening and the mid polar fraction demonstrated significant activity against cancer cell lines. During phase two, advanced separation technology using flash chromatography resulted in the separation of several fractions which were pooled based on thin layer chromatography similarities (TLC) (data not shown). The pooled fractions were subjected to bioactivity screening. The most bioactive fraction was found to have a major compound by TLC which upon 


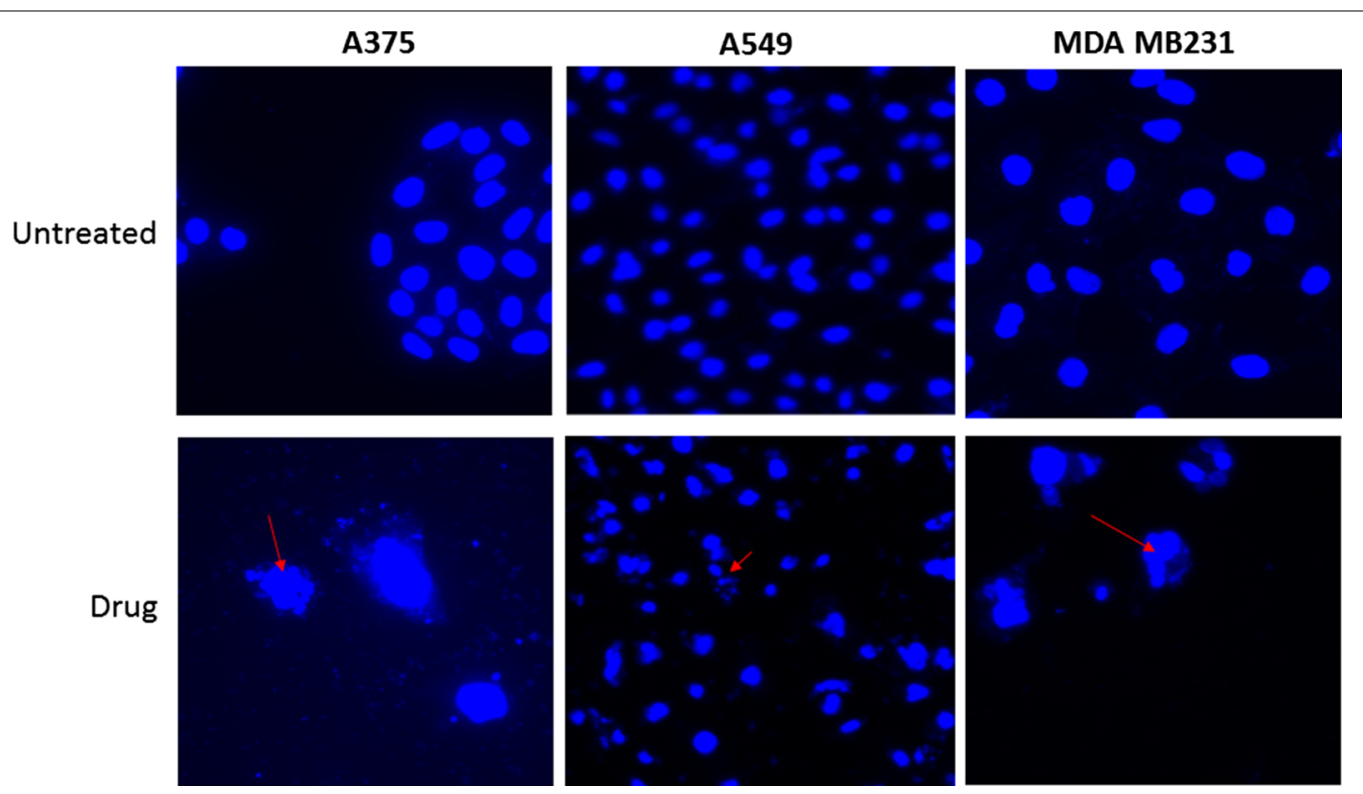

Fig. 7 In-cell DNA fragmentation effect of HLBT-100 against the following cell lines: A375, A459 and MDA MB231 was evaluated. $1-2 \times 10^{5}$ cells were seeded on glass coverslip in 12 well cell culture plate (costar, USA) and treated with drug. An equal vol of $10 \%$ formalin was added in each well for 10-15 min at RT. The plate was centrifuged at 3000 $\mathrm{g}$ for $20 \mathrm{~min}$ to spin down all the cells. Liquid was discarded and cells were treated with $0.1 \%$ Triton X100 for 5 min and removed from triton. Cells were treated with DAPI $(0.5 \mu \mathrm{g} / \mathrm{ml})$ in $0.1 \%$ BSA for 5 min and washed $3 \times$ with normal saline. Finally, the cells were mounted with mowiol (sigma) and transferred onto microscopic glass slides, dried in dark and visualized under fluorescence microscope (Nikon and Zeiss, USA). Effect of HLBT-100 on fragmented is indicated by arrows

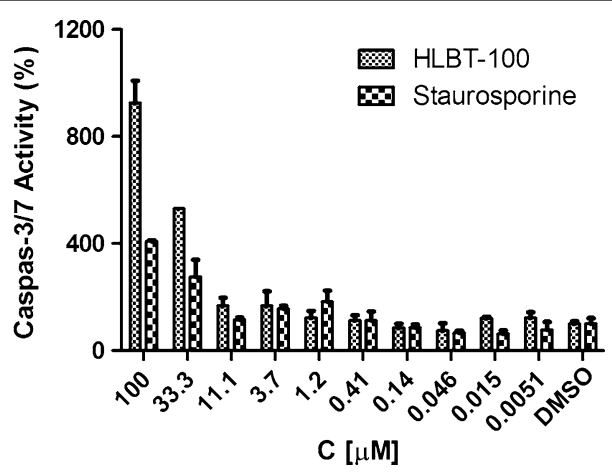

Fig. 8 The Apo-ONE ${ }^{\circledR}$ Homogeneous Caspase-3/7 Assay (Promega) was used to detect caspase-3/7 activity of HLBT-100 based on the cleavage of a pro-fluorescent DEVD peptide-rhodamine 110 substrate [(Z-DEVD)2-R110] according to manufacturer's instruction and as reported by Wagner et al. [78]. PC-3 prostate cancer cell line was cultured in F12 K medium supplemented with $10 \% \mathrm{FBS}$ and $100 \mu \mathrm{g} / \mathrm{ml}$ penicillin, and $100 \mu \mathrm{g} / \mathrm{ml}$ streptomycin. PC-3 cells were treated with HLBT-100 or reference compound staurosporine for $6 \mathrm{~h}$ with serum free medium. The activation was considered significant only when the highest compound dose induced caspase-3/7 activity $\geq 200 \%$ compared to DMSO

further purification yielded a pale yellowish powder and was identified to be a flavanone based on NMR and HRMS analysis (Fig. 10).

\section{Anti-proliferative assay Cell lines and culture medium}

Five human cancer cell lines (U87 MG, MDA-MB-231, MV4-11, PC-3 and A375 were obtained from American Type Culture Collection (ATCC) (Manassas, VA, USA). The five tumor cell lines were maintained in minimum essential media supplemented with $10 \%$ fetal calf serum (Thermo Scientific, USA), 1\% L-glutamine, $2 \%$ penicillin-streptomycin, and $0.2 \%$ gentamicin all from Corning Cellgro Mediatech, Inc. (Manassas, USA). The two CNS related cell lines, cancer cell line (-IMR-32) and a normal cell (neuro-2a) were maintained at Reaction Biology Corp.

\section{Anticancer cell proliferation and cytotoxicity assay}

The WST-1 (4-[3-(4-iodophenyl)-2-(4-nitrophenyl)-2H5-tetrazolio]-1,3-benzene disulfonate) (Roche) colorimetric assay was used [74]. Briefly, cells were trypsinized and plated into 96 well plates in $50 \mu \mathrm{l}$ of media and incubated overnight. Approximately $18 \mathrm{~h}$ after plating, $50 \mu \mathrm{l}$ of media containing the required drug concentration was added per well. The compounds and extracts were solubilized in DMSO. The cells were allowed to proliferate for $72 \mathrm{~h} 37{ }^{\circ} \mathrm{C}$ in humidified atmosphere of $5 \% \mathrm{CO}_{2}$. The experiment is terminated using WST-1 (Roche) $10 \mu \mathrm{l}$ per well and absorbance is read at $450 / 690 \mathrm{~nm}$. 


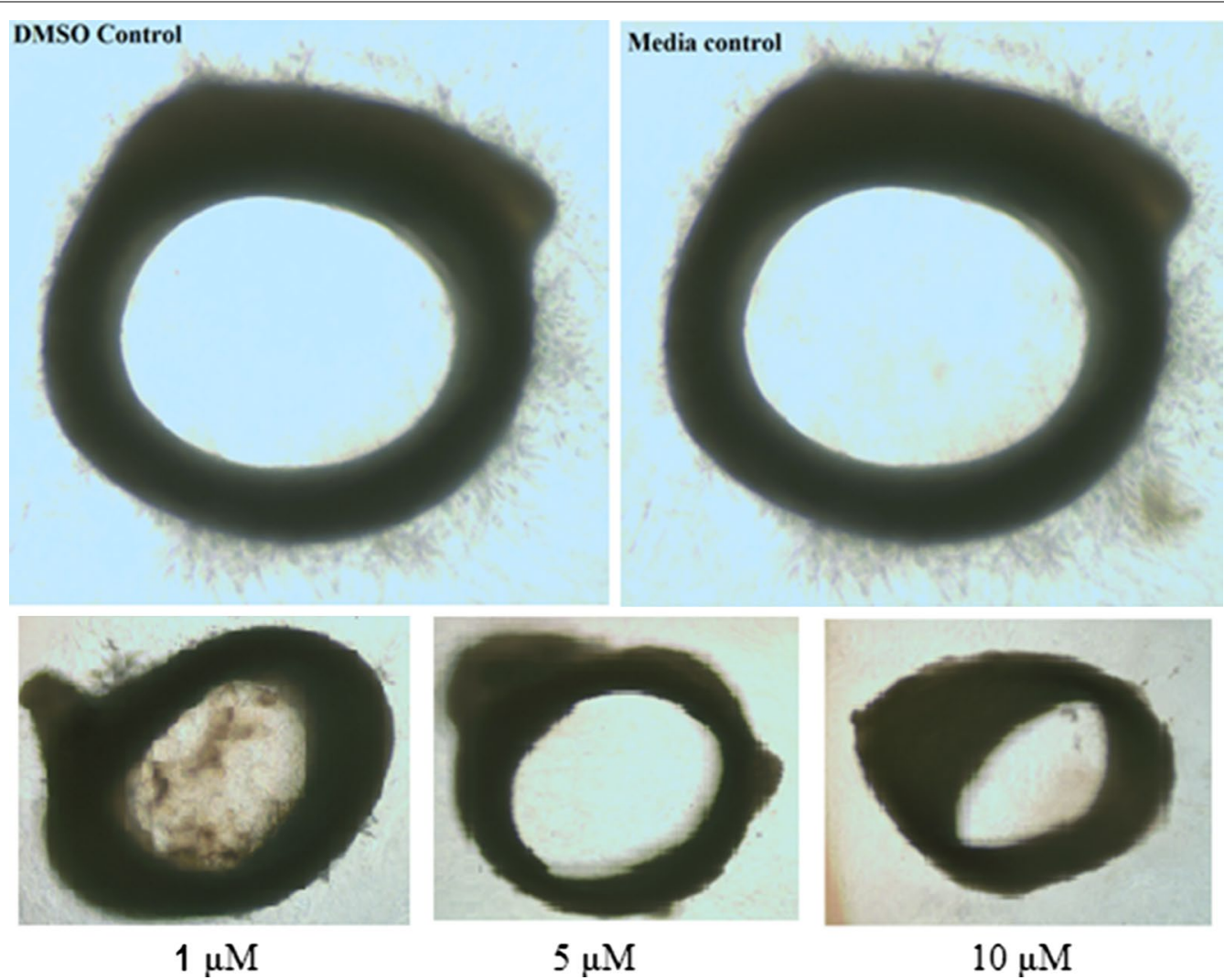

Fig. 9 Antiangiogenic activity of HLBT-100. The rat ring aortic assay as was used to determine effect on capillary sprout formation. HLBT-100 inhibited sprout formation at all 3 concentrations tested ( $1 \mu \mathrm{M}$ lowest concentration) compared to the DMSO and media controls

Antiproliferation activity was assessed as a percentage of proliferation of untreated cells, and $\mathrm{IC}_{50}$ values determined using Graphpad Prism software (Version 6.01). All concentrations are treated in duplicate and the mean results determined are automatically used in the $\mathrm{IC}_{50}$ determination. The anticancer activity against the NCI60 cancer cell lines panel was performed using NCI's standard protocol [75].

\section{CellTiter-Glo ${ }^{\circledR}$ luminescent cell viability assay}

Cells were seeded at 2000-5000 cells/well in 96-well plates. After an overnight incubation, cells were treated with drug and incubated for $72 \mathrm{~h}$ at $37{ }^{\circ} \mathrm{C}$. The cell viability was determined using the Cell Titer-Glo luminescent cell viability assay kit (Promega, Madison, WI, USA) after staining for $10 \mathrm{~min}$, according to the manufacturer's instructions. The half-maximal inhibitory concentration $\left(\mathrm{IC}_{50}\right)$ values were calculated using Graph Pad Prism software (Version 6.01).

\section{Cell cycle arrest and apoptosis determination studies}

The MV4-11 leukemic cell line was used determine the cell cycle arrest and apoptotic effects of HLBT-100. Cell were treated with either DMSO (vehicle) or HLBT-100. At
24, 48 and $72 \mathrm{~h}$, cells were harvested, washed and stained according to the manufacturer's recommendations with the Abcam propidium iodide flow cytometry kit (Abcam, Cambridge, MA, USA) for cell cycle determination and the Annexin V-FITC apoptosis detection Kit I for apoptosis assessment (BD Biosciences, San Jose, CA, USA). Samples stained for Annexin V-FITC analysis and Propidium Iodide were acquired using BD FACS Canto II (BD Biosciences, San Jose, CA, USA). Acquired samples were analyzed using FlowJo (Tree Star, Ashland, OR, USA).

\section{In-cell DNA fragmentation assay}

The method used for nuclear DNA fragmentation has been described previously [76, 77] with slight modification. Briefly, $1-2 \times 10^{5}$ cells were seeded on the glass coverslip in 12 well cell culture plate (costar, USA). The cells were treated with the drugs and at the end of treatment equal vol of $10 \%$ formalin was added in each well for $10-15 \mathrm{~min}$ at RT. The plate was centrifuged at $3000 \mathrm{~g}$ for $20 \mathrm{~min}$ to spin down all the cells. The liquid was discarded and cells were treated with $0.1 \%$ Triton X100 for $5 \mathrm{~min}$ and after that, the triton was removed. In the next step, Cells were treated with DAPI $(0.5 \mu \mathrm{g} /$ $\mathrm{ml}$ ) in $0.1 \%$ BSA for $5 \mathrm{~min}$ and washed three times with 
normal saline. Finally, the cells were mounted with mowiol (sigma) and transferred onto microscopic glass slides, dried in dark and visualized under fluorescence microscope (Nikon and Zeiss, USA).

\section{Caspase $3 / 7$ activation}

The Apo-ONE ${ }^{\circledR}$ Homogeneous Caspase-3/7 Assay (Promega) was used to detect caspase-3/7 activity based on the cleavage of a pro-fluorescent DEVD peptide-rhodamine 110 substrate [(Z-DEVD)2-R110] according to manufacturer's instruction and as reported by Wagner et al. [78]. PC-3 prostate cancer cell line was cultured in F12K medium supplemented with $10 \%$ FBS and $100 \mu \mathrm{g} / \mathrm{ml}$ penicillin, and $100 \mu \mathrm{g} / \mathrm{ml}$ streptomycin. PC-3 cells were treated with HLBT-100 or reference compound staurosporine for $6 \mathrm{~h}$ with serum free medium. The activation was considered significant only when the highest compound dose induced caspase- $3 / 7$ activity $\geq 200 \%$ compared to DMSO.

\section{Angiogenesis}

The assay was carried out as previous reported with modification to determine the antiangiogenic activity of HLBT-100 [63, 79]. Briefly, a 170 g (5-6 weeks old) Sprague-Dawley rat (Harlan, Frederick, Maryland) was euthanized by $\mathrm{CO}_{2}$ asphyxiation. All rats used were maintained in the vivarium at the Institute of Human Virology at the University of Maryland, School of Medicine in accordance with the Institutional Animal Care and Use Committee (IACUC) guidelines. The aorta was dissected using a dissecting microscope and the periaortic fibroadipose tissue was removed and 1-2 $\mathrm{mm}$ long aortic rings were sectioned and rinsed extensively in EBM media (endothelial cell basal media). The rings were embedded in $200 \mu \mathrm{l}$ of matrigel in 24-well culture plates so that the lumen was parallel to the base of the plate. $800 \mu \mathrm{l}$ of EBM without ECGS was added to each well. The rings were incubated for $24 \mathrm{~h}$ in an incubator at $37{ }^{\circ} \mathrm{C}$ and $5 \% \mathrm{CO}_{2}$ in humidified air and the media was replaced with fresh $800 \mu \mathrm{l}$ of EBM with ECGS having varying concentrations of HLBT-100. The rings were further incubated for 4-5 days and evaluated for sprout formation. Capillary sprout formation compared to control were captured with a Nikon FDX-35 camera mounted onto a Nikon Eclipse TE300 microscope.

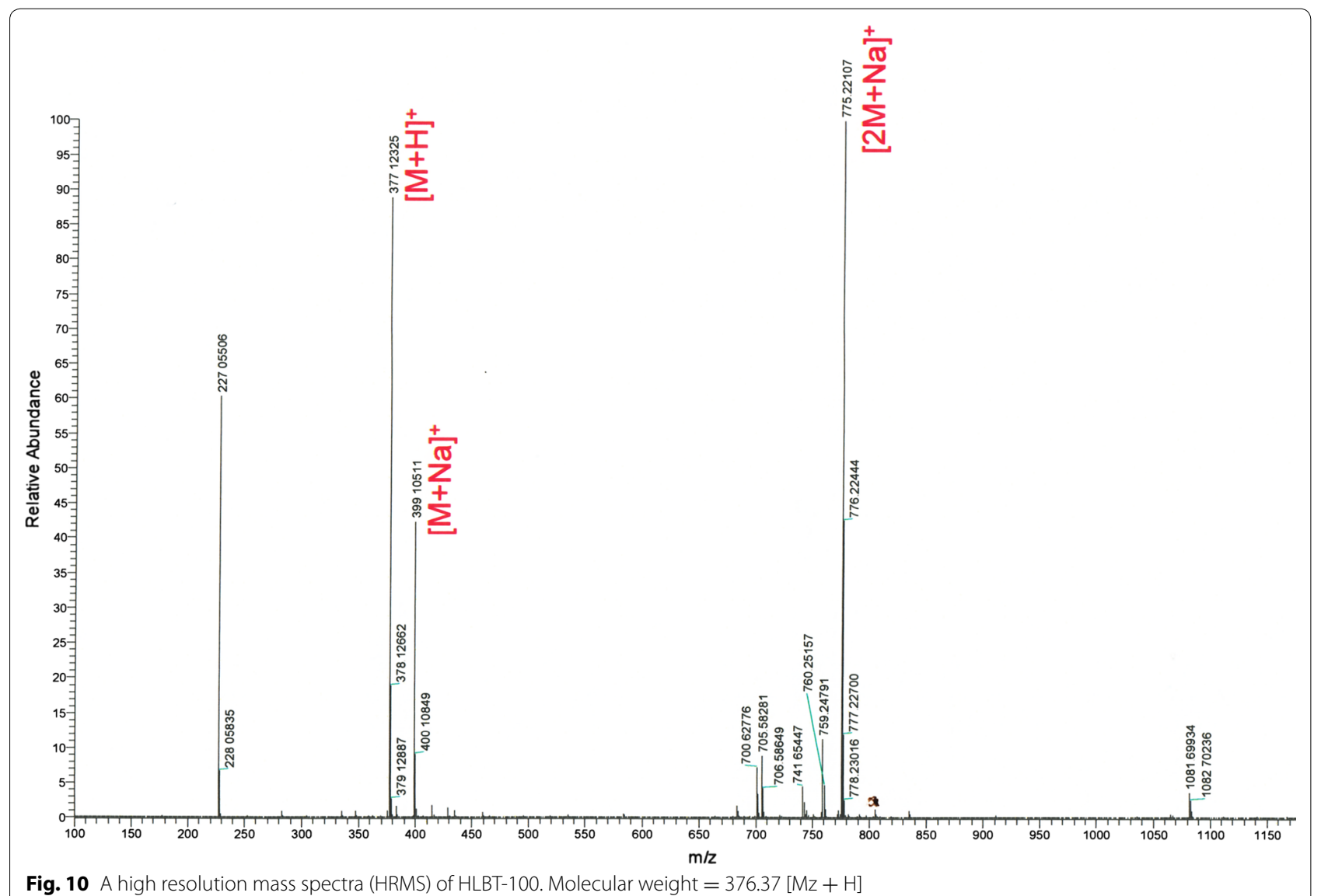

Fig. 10 A high resolution mass spectra (HRMS) of HLBT-100. Molecular weight $=376.37[\mathrm{Mz}+\mathrm{H}]$ 


\section{Statistical analysis}

All experiments where required were run with replicates and the means used in the analysis and $\mathrm{IC}_{50}$ values generated and graphing of data done by Graph Pad Prism software (Version 6.01).

\begin{abstract}
Abbreviations
ATCC: American Type Culture Collection; $\mathrm{Cdk}$ : cyclin dependent kinase; $\mathrm{CO}_{2}$ : carbon dioxide; DAPI: 4',6-diamidino-2-phenylindole; DNA: dioxyribonucleic acid; $\mathrm{DiH}_{2} \mathrm{O}$ : distilled water; DMSO: dimethyl sulfoxide; EBM: endothelial basal medium; ECGS: endothelial cell growth supplement; FITC: flourescein; HRMS: high resolution mass spectrometry; HUVEC: human umbilical vein endothelial cell; IACUC: Institutional Animal Care and Use Committee; MS: mass spectrometry; NCl: National Cancer Institute; NMR: nuclear magnetic resonance spectroscopy; SFE: supercritical fluid extraction; TLC: thinlayer chromatography; VEGFR: vascular endothelial growth factor receptor; WHO: World Health Organization; WST-1: water-soluble tetrazolium salts.
\end{abstract}

\section{Authors' contributions}

Conceived and designed the experiments: $\mathrm{HL}, \mathrm{NT}$ and JB, Acquisition of data: CW, KA and NT, Analyzed and interpreted the data: NT, CW and KA. Wrote the paper: NT, JB and HL, Critical and intellectual revision of the article contents: NT, HL and JB. All authors read and approved the final manuscript.

\section{Author details}

${ }^{1}$ Bio-Tech R\&D Institute, University of the West Indies, 6 St. Johns Close, Mona, Jamaica. ${ }^{2}$ Educational \& Scientific LLC, 725 W Lombard St, Baltimore, MD 21201, USA. ${ }^{3}$ Institute of Human Virology, University of Maryland School of Medicine, 725 W Lombard St, Baltimore, MD, USA.

\section{Acknowledgements}

The authors are grateful to Dr. Rena Lapidus and Brandon Cooper of the Translational Core Laboratory of the Cancer Center, University of Maryland School of Medicine for validating the results of the anticancer activity of HLBT-100 and the National Cancer Institute for the screening of HLBT-100 in the NCl-60 cancer panel. Harry Davis and Dr. Eugene Ateh of IHV, University of Maryland School of Medicine are appreciated for their technical support. The University of the West Indies is acknowledged for its support of the research activities of Bio-Tech R\&D Institute.

\section{Competing interests}

Authors HL and NT are employees of Educational \& Scientific LLC which has interest in the commercial development of HLBT-100. All other authors declare no competing interests.

\section{Ethics approval and consent to participate}

All rats used were maintained in the vivarium at the Institute of Human Virology at the University of Maryland, School of Medicine in accordance with the University of Maryland Institutional Animal Care and Use Committee (IACUC) guidelines.

Received: 15 September 2016 Accepted: 16 February 2017

Published online: 07 March 2017

\section{References}

1. Siegel RL, Miller KD, Jemal A. Cancer statistics, 2016. CA Cancer J Clin. 2016;66(1):7-30.

2. WHO Cancer Fact Sheet No. 297. http://www.who.int/mediacentre/ factsheets/fs297/en/. Accessed 3 Sept 2016.

3. US National Cancer Institute Cancer Statistics. http://www.cancer.gov/ about-cancer/understanding/statistics. Accessed 3 Sept 2016.

4. Jemal A, Center MM, DeSantis C, Ward EM. Global patterns of cancer incidence and mortality rates and trends. Cancer Epidemiol Biomark Prev. 2010;19(8):1893-907.
5. Lowy DR, Collins FS. Aiming high — changing the trajectory for cancer. N Engl J Med. 2016;374(20):1901-4.

6. Newman DJ, Cragg GM. Natural products as sources of new drugs over the 30 years from 1981 to 2010. J Nat Prod. 2012;75(3):311-35.

7. Cragg GM, Grothaus PG, Newman DJ. Impact of natural products on developing new anti-cancer agents. Chem Rev. 2009;109(7):3012-43.

8. Bernhoft A. A brief review. In: Bernhoft A, editor. Bioactive compounds in plants benefits and risks for man and animals. Oslo, Norway: The Norwegian Academy of Science and Letters; 2010. pp. 11-7.

9. Azmir J, Zaidul I, Rahman M, Sharif K, Mohamed A, Sahena F, Jahurul M, Ghafoor K, Norulaini N, Omar A. Techniques for extraction of bioactive compounds from plant materials: a review. J Food Eng. 2013;117(4):426-36.

10. Bernal R, Valverde T, Hernandez-Rosas L. Habitat preference of the epiphyte Tillandsia recurvata (Bromeliaceae) in a semi-desert environment in Central Mexico. Botany. 2005;83(10):1238-47.

11. Gechev TS, Hille J, Woerdenbag HJ, Benina M, Mehterov N, Toneva V, Fernie AR, Mueller-Roeber B. Natural products from resurrection plants: potential for medical applications. Biotechnol Adv. 2014;32(6):1091-101.

12. de Queiroga MA, de Andrade LM, Florêncio KC, de Fátima Agra M, da Silva MS, Barbosa-Filho JM, da-Cunha EVL. Chemical constituents from Tillandsia recurvata. Fitoterapia. 2004;75(3):423-5.

13. Cabrera GM, Seldes AM. Hydroperoxycycloartanes from Tillandsia recurvata. J Nat Prod. 1995;58(12):1920-4.

14. Lowe $H$, Toyang N, Bryant J. In vitro and In vivo anti-cancer effects of Tillandsia recurvata (Ball Moss) from Jamaica. West Indian Med J. 2013;62(3):177-80.

15. Lowe HI, Toyang NJ, Charah Watson SB, Bahado-Singh P, Bryant J. In vitro anticancer activity of the crude extract and two dicinnamate isolates from the Jamaican Ball Moss (Tillandsia recurvata L.). Am Int J Contemp Res. 2013;3(1):93.

16. Lowe H, Watson CT, Badal S, Ateh EN, Toyang NJ, Bryant J. Antiangiogenic properties of the Jamaican ball moss (Tillandsia recurvata L.). Int Res J Biol Sci. 2012;1:73-6.

17. Lowe HI, Watson CT, Badal S, Toyang NJ, Bryant J. Cycloartane-3,24,25-triol inhibits MRCKa kinase and demonstrates promising anti prostate cancer activity in vitro. Cancer Cell Int. 2012;12(1):1.

18. Lowe HI, Watson CT, Badal S, Toyang NJ, Bryant J. Kinase inhibition by the Jamaican ball moss, Tillandsia recurvata $\mathrm{L}$. Anticancer Res. 2012;32(10):4419-22.

19. Hollman $\mathrm{PCH}$, Katan M. Dietary flavonoids: intake, health effects and bioavailability. Food Chem Toxicol. 1999;37(9):937-42.

20. Martínez-Pérez C, Ward C, Turnbull AK, Mullen P, Cook G, Meehan J, Jarman EJ, Thomson PI, Campbell CJ, MCPhail D. Antitumour activity of the novel flavonoid Oncamex in preclinical breast cancer models. Br J Cancer. 2016;114(8):905-16.

21. Beecher GR. Overview of dietary flavonoids: nomenclature, occurrence and intake. J Nutr. 2003;133(10):3248S-54S.

22. Corradini E, Foglia P, Giansanti P, Gubbiotti R, Samperi R, Laganà A. Flavonoids: chemical properties and analytical methodologies of identification and quantitation in foods and plants. Nat Prod Res. 2011;25(5):469-95.

23. Iwashina T. The structure and distribution of the flavonoids in plants. J Plant Res. 2000;113(3):287-99.

24. Maru G, Kumar G, Ghantasala S, Tajpara P. Polyphenol (s)-mediated in vivo cellular responses during carcinogenesis. Polyphenols in health and diseases. Amsterdam: Elsevier; 2014. p. 1141-79.

25. Tapas AR, Sakarkar D, Kakde R. Flavonoids as nutraceuticals: a review. Trop J Pharm Res. 2008;7(3):1089-99.

26. War AR, Paulraj MG, Ahmad T, Buhroo AA, Hussain B, Ignacimuthu $S$, Sharma HC. Mechanisms of plant defense against insect herbivores. Plant Signal Behav. 2012;7(10):1306-20.

27. Treutter D. Significance of flavonoids in plant resistance and enhancement of their biosynthesis. Plant Biol. 2005;7(06):581-91.

28. Field B, Jordán F, Osbourn A. First encounters-deployment of defencerelated natural products by plants. New Phytol. 2006;172(2):193-207.

29. Janakiram NB, Mohammed A, Madka V, Kumar G, Rao CV. Prevention and treatment of cancers by immune modulating nutrients. Mol Nutr Food Res. 2016;60:1275.

30. Yao LH, Jiang Y, SHI J, Tomas-Barberan F, Datta N, Singanusong R, Chen S. Flavonoids in food and their health benefits. Plant Foods Hum Nutr. 2004;59(3):113-22. 
31. Stapel J, Oppermann C, Richter D, Ruth W, Briese V. Polyphenol compounds with anti-carcinogenic qualities: effects of quercetin (flavonol), chrysin (flavon), kaempferol (flavanol), naringenin (flavanon) and hesperidin (flavanoid) on in vitro breast cancer. J Med Plants Res. 2013;7(29):2187-96.

32. Cushnie TT, Lamb AJ. Antimicrobial activity of flavonoids. Int J Antimicrob Agents. 2005;26(5):343-56.

33. Li Y-L, Ma S-C, Yang Y-T, Ye S-M, But PP-H. Antiviral activities of flavonoids and organic acid from Trollius chinensis Bunge. J Ethnopharmacol. 2002;79(3):365-8.

34. Khan MK, Dangles O. A comprehensive review on flavanones, the major citrus polyphenols. J Food Compos Anal. 2014;33(1):85-104.

35. El Gharras H. Polyphenols: food sources, properties and applications-a review. Int J Food Sci Technol. 2009;44(12):2512-8.

36. Taylor RC, Cullen SP, Martin SJ. Apoptosis: controlled demolition at the cellular level. Nat Rev Mol Cell Biol. 2008;9(3):231-41.

37. Chun OK, Chung SJ, Song WO. Estimated dietary flavonoid intake and major food sources of US adults. J Nutr. 2007;137(5):1244-52.

38. Ren W, Qiao Z, Wang H, Zhu L, Zhang L. Flavonoids: promising anticancer agents. Med Res Rev. 2003;23(4):519-34.

39. Hertog MG, Feskens EJ, Kromhout D, Hollman P, Katan M. Dietary antioxidant flavonoids and risk of coronary heart disease: the Zutphen Elderly Study. Lancet. 1993;342(8878):1007-11.

40. Shukla S, Gupta S. Apigenin: a promising molecule for cancer prevention. Pharm Res. 2010;27(6):962-78.

41. Ferrari C, Torres E. Biochemical pharmacology of functional foods and prevention of chronic diseases of aging. Biomed Pharmacother. 2003;57(5):251-60.

42. Chen J, Mangelinckx S, Adams A, Wang Z, Li W, De Kimpe N. Natural flavonoids as potential herbal medication for the treatment of diabetes mellitus and its complications. Nat Prod Commun. 2015;10(1):187-200.

43. van Dam RM, Naidoo N, Landberg R. Dietary flavonoids and the development of type 2 diabetes and cardiovascular diseases: review of recent findings. Curr Opin Lipidol. 2013;24(1):25-33.

44. Peluso I, Miglio C, Morabito G, loannone F, Serafini M. Flavonoids and immune function in human: a systematic review. Crit Rev Food Sci Nutr. 2015;55(3):383-95.

45. Cabrera M, Simoens M, Falchi G, Lavaggi ML, Piro OE, Castellano EE, Vidal A, Azqueta A, Monge A, de Cerain AL. Synthetic chalcones, flavanones, and flavones as antitumoral agents: biological evaluation and structureactivity relationships. Bioorg Med Chem. 2007;15(10):3356-67.

46. Arul D, Subramanian P. Naringenin (citrus flavonone) induces growth inhi bition, cell cycle arrest and apoptosis in human hepatocellular carcinoma cells. Pathol Oncol Res. 2013:19(4):763-70.

47. Li C, Schluesener H. Health-promoting effects of the citrus flavanone hesperidin. Critical Rev Food Sci Nutr. 2014 (just-accepted).

48. Shoemaker $\mathrm{RH}$. The $\mathrm{NCl} 60$ human tumour cell line anticancer drug screen. Nat Rev Cancer. 2006;6(10):813-23.

49. Holbeck SL, Collins JM, Doroshow JH. Analysis of Food and Drug Administration-approved anticancer agents in the NCl60 panel of human tumor cell lines. Mol Cancer Ther. 2010;9(5):1451-60.

50. Chabner BA. NCl-60 cell line screening: a radical departure in its time. J Natl Cancer Inst. 2016;108(5):djv388.

51. LePage KT, Dickey RW, Gerwick WH, Jester EL, Murray TF. On the use of neuro-2a neuroblastoma cells versus intact neurons in primary culture for neurotoxicity studies. Crit Rev Neurobiol. 2005;17(1):27-50.

52. Ashkenazi A. Targeting the extrinsic apoptosis pathway in cancer. Cytokine Growth Factor Rev. 2008;19(3):325-31.

53. Mcllwain DR, Berger T, Mak TW. Caspase functions in cell death and disease. Cold Spring Harb Perspect Biol. 2013;5(4):a008656.

54. Slee EA, Adrain C, Martin SJ. Executioner caspase-3,-6, and -7 perform distinct, non-redundant roles during the demolition phase of apoptosis. J Biol Chem. 2001;276(10):7320-6.

55. Chan FL, Choi H, Chen Z, Chan PS, Huang Y. Induction of apoptosis in prostate cancer cell lines by a flavonoid, baicalin. Cancer Lett. 2000;160(2):219-28.

56. Choi EJ, Kim G-H. Apigenin induces apoptosis through a mitochondria/ caspase-pathway in human breast cancer MDA-MB-453 cells. J Clin Biochem Nutr. 2009;44(3):260-5.
57. Woo Y, Shin SY, Hyun J, Lee SD, Lee YH, Lim Y. Flavanones inhibit the clonogenicity of HCT116 cololectal cancer cells. Int J Mol Med. 2012;29(3):403-8.

58. Ramos S. Effects of dietary flavonoids on apoptotic pathways related to cancer chemoprevention. J Nutr Biochem. 2007:18(7):427-42.

59. Chen D, Daniel KG, Chen MS, Kuhn DJ, Landis-Piwowar KR, Dou QP. Dietary flavonoids as proteasome inhibitors and apoptosis inducers in human leukemia cells. Biochem Pharmacol. 2005;69(10):1421-32.

60. Suh Y, Afaq F, Johnson JJ, Mukhtar H. A plant flavonoid fisetin induces apoptosis in colon cancer cells by inhibition of COX2 and Wnt/EGFR/ NF-kB-signaling pathways. Carcinogenesis. 2009:30(2):300-7.

61. Birbrair A, Zhang T, Wang Z-M, Messi ML, Olson JD, Mintz A, Delbono O. Type-2 pericytes participate in normal and tumoral angiogenesis. Am J Physiol Cell Physiol. 2014;307(1):C25-38.

62. Folkman J. Tumor angiogenesis: therapeutic implications. N Engl J Med. 1971:285(21):1182-6.

63. Grant DS, Williams TL, Zahaczewsky M, Dicker AP. Comparison of antiangiogenic activities using paclitaxel (taxol) and docetaxel (taxotere). Int J Cancer. 2003;104(1):121-9.

64. Mojzis J, Varinska L, Mojzisova G, Kostova I, Mirossay L. Antiangiogenic effects of flavonoids and chalcones. Pharmacol Res. 2008;57(4):259-65.

65. Pfeffer U, Ferrari N, Morini M, Benelli R, Noonan D, Albini A. Antiangiogenic activity of chemopreventive drugs. Int J Biol Markers. 2002;18(1):70-4.

66. Nijveldt RJ, Van Nood E, Van Hoorn DE, Boelens PG, Van Norren K, Van Leeuwen PA. Flavonoids: a review of probable mechanisms of action and potential applications. Am J Clin Nutr. 2001;74(4):418-25.

67. Anand K, Sarkar A, Kumar A, Ambasta RK, Kumar P. Combinatorial antitumor effect of naringenin and curcumin elicit angioinhibitory activities in vivo. Nutr Cancer. 2012;64(5):714-24.

68. Newcomb EW. Flavopiridol: pleiotropic biological effects enhance its anti-cancer activity. Anticancer Drugs. 2004;15(5):411-9.

69. Bergers $G$, Hanahan D. Modes of resistance to anti-angiogenic therapy. Nat Rev Cancer. 2008;8(8):592-603.

70. Ferrara N, Kerbel RS. Angiogenesis as a therapeutic target. Nature 2005:438(7070):967-74.

71. Byrd JC, Peterson BL, Gabrilove J, Odenike OM, Grever MR, Rai K, Larson RA, Cancer BLG. Treatment of relapsed chronic lymphocytic leukemia by 72-hour continuous infusion or 1-hour bolus infusion of flavopiridol: results from Cancer and Leukemia Group B study 19805. Clin Cancer Res. 2005;11(11):4176-81.

72. Zeidner JF, Foster MC, Blackford AL, Litzow MR, Morris LE, Strickland SA Lancet JE, Bose P, Levy MY, Tibes R. Randomized multicenter phase 2 study of flavopiridol (alvocidib), cytarabine, and mitoxantrone (FLAM) versus cytarabine/daunorubicin $(7+3)$ in newly diagnosed acute myeloid leukemia. haematologica. 2015:haematol. 2015.125849.

73. Tran C, Ouk S, Clegg NJ, Chen Y, Watson PA, Arora V, Wongvipat J, Smith-Jones PM, Yoo D, Kwon A. Development of a second-generation antiandrogen for treatment of advanced prostate cancer. Science. 2009;324(5928):787-90

74. Ngamwongsatit P, Banada PP, Panbangred W, Bhunia AK. WST-1-based cell cytotoxicity assay as a substitute for MTT-based assay for rapid detection of toxigenic Bacillus species using $\mathrm{CHO}$ cell line. J Microbiol Methods. 2008;73(3):211-5

75. NCl-60 screening methodology. https://dtp.cancer.gov/discovery development/nci-60/methodology.htm. Accessed 2 Sept 2016.

76. Chazotte B. Labeling nuclear DNA using DAPI. Cold Spring Harbor Protoc. 2011;2011(1):pdb-prot5556

77. Raufman JP, Shant J, Guo CY, Roy S, Cheng K. Deoxycholyltaurine rescues human colon cancer cells from apoptosis by activating EGFR-dependent PI3 K/Akt signaling. J Cell Physiol. 2008;215(2):538-49.

78. Wagner K-D, Wagner N, Wellmann S, Schley G, Bondke A, Theres H, Scholz H. Oxygen-regulated expression of the Wilms'tumor suppressor Wt1 involves hypoxia-inducible factor-1 (HIF-1). FASEB J. 2003;17(10):1364-6.

79. Toyang NJ, Wabo HK, Ateh EN, Davis H, Tane P, Kimbu SF, Sondengam LB, Bryant J. In vitro anti-prostate cancer and ex vivo antiangiogenic activity of Vernonia guineensis Benth. (Asteraceae) tuber extracts. J Ethnopharmacol. 2012:141(3):866-71. 